\title{
Rethinking the law and politics of democratic police accountability
}

\author{
Dr John LM McDaniel \\ BBS (Hons), MA, PhD, FHEA \\ Senior Lecturer in Policing and Criminal Justice \\ School of Social, Historical and Political Studies \\ Faculty of Social Sciences \\ Mary Seacole Building \\ University of Wolverhampton \\ Nursery Street \\ Wolverhampton \\ WV1 1AD \\ United Kingdom \\ Tel: +44 (0) 1902323512 \\ Email: J.McDaniel@wlv.ac.uk
}

Published in:

The Police Journal: Theory, Practice and Principles

DOI 10.1177/0032258X16685107 


\begin{abstract}
$\underline{\text { Abstract }}$
This paper evaluates the work and impact of a number of Police and Crime Commissioners (PCCs) in England and Wales and attempts to refocus public discourse and scrutiny on their Police and Crime Plans as a key prism through which their performance should be measured. Drawing upon the literature published by various PCCs, the Stevens Commission, the Home Affairs Committee and numerous academics, the paper will argue that a major reform of democratic police accountability in England and Wales is needed. Due to the often voluminous and piecemeal nature of the documents published on the PCCs' websites, the textual analysis is limited to the Police and Crime Plans for Greater Manchester, the West Midlands and the London Metropolitan area.
\end{abstract}

\title{
Introduction
}

The academic literature on the subject of PCCs has been less than flattering. In 2013, the Stevens Commission (2013, p.17) found that the radical 'individual' PCC model of accountability had structural defects and 'serious deficiencies that cannot easily be fixed'. The Commission, which was established by the formal political opposition at the time, published its report while the PCC model was still in its infancy. It raised issues of 'invisibility' of PCCs to the public, poor electoral turnout, and priority of party interests; ultimately concluding that the PCC model was 'an experiment that is failing', 'systematically flawed' and 'should be discontinued' (ibid, p.80-84). Despite these early criticisms, following a trawl of the extant literature, Caless and Owens (2016, p.143) concluded in 2016 that there are still "no published analyses of the PCC/ public interaction and we are not aware of any critical or statistical analyses of the effectiveness or quality of contacts between PCCs and the people whom the former claim to represent'. The absence of research on the work and successes of PCCs is startling. Caless and Owens contributed to the relatively barren landscape by arranging and transcribing interviews with 23 (of 41) PCCs with a view to shedding some invaluable light on the attitudes of PCCs and chief constables towards police governance, community engagement, collaborative working and social media. Lister and Rowe (2015) also contributed to the scrutiny of PCCs by carrying out a content-analysis of the election statements of the first cohort of PCCs with a view to gauging the political nature of the construct. The Home Affairs Committee (HAC), in turn, has carried out two reviews of the PCC construct, in 2014 and 2016 respectively. The paper will refer to these reports and academic studies throughout and will add to the limited field of research by focusing more particularly on the form and nature of the PCCs' Police and Crime Plans. It will argue that the plans should serve as a key benchmark for measuring the success and legitimacy of PCCs.

The political rationale for introducing perhaps the most significant constitutional change in policing in England and Wales has been examined in some depth in the aforementioned literature. The prevailing consensus is that the idea for the PCC construct germinated within Policy Exchange, a Conservative think-tank, in the mid-2000s and was zealously promoted thereafter by the think-tank's chairman, Michael Gove MP (Caless and Owens 2016). One catalyst was a report called 'Closing the Gap' (2005) by Her Majesty's Inspectorate of Constabulary (HMIC) which found that the detrimental effects of anti-social behaviour hardly registered with local police services or the Home Office who tended to treat it as a low-level offence. More broadly, HMIC found that very few forces which it assessed fully met the requisite range of benchmark standards. The appointment of a directly-elected 
individual to hold each police force to account was considered necessary to counteract rising crime rates, the ineffectiveness of Police Authorities and the increasing centralisation of strategic authority for policing under the sitting Labour Government (Caless and Owens 2016). The Police Authorities, part-time committees of councillors and magistrates which dated back to 1964, were considered to be amateurish, unorganised, "unelected to that job, unaccountable, uncontactable and frankly unknown” (HAC 2016, p.17-18). On a political level, the Conservative Party was also keen to pursue a policy of 'new localism' which promised to bring an end to the centralism associated with the Labour Government (Raine 2016). Newburn (2012) found that although the American style of mayoral police governance served as a partial inspiration for the PCC construct, the subsequent model was a unique English creation. In the run up to the 2010 general election, the Conservative Party manifesto promised to 'replace the existing, invisible and unaccountable police authorities and make the police accountable to a directly-elected individual who will set policing priorities for local communities' (HAC 2010, p.3). It was argued that PCCs would realise real local accountability by putting policing back in the hands of the public (ibid). Caless (2011, p.142) comments that Gove's views on the necessity of a single directly-elected individual to govern policing had quickly become 'political orthodoxy'.

\section{The 'Police and Crime Plan': a device for community-oriented policing}

It is important to examine this 'orthodoxy' through the prism of the PCCs' Police and Crime Plans because the plans form a central part of a PCCs functions. The Police Reform and Social Responsibility Act (2011, s.5.1) states in the very first section of the chapter on 'Functions' that 'the police and crime commissioner for a police area must issue a police and crime plan within the financial year in which each ordinary election is held'. The plan must be issued 'as soon as practicable after the commissioner takes office' and a commissioner may vary the plan or issue a new one at any time (2011, s.5.2 - s.5.4). The plan must set out: the commissioner's 'police and crime objectives' for crime and disorder reduction in that area; 'the policing of the police area' which the chief officer of police is to provide; the financial and other resources which the PCC is to provide; and the means by which the chief officer's performance will be measured, amongst other things (2011, s.7). Most importantly, sections 14 and 17 of the Act emphasise the requirement for the plans to reflect the ethos of 'community-oriented policing'.

The theory of community-oriented policing holds that the primary job of a police force is not to independently eradicate crime with little or no concern for targeting the underlying causes of crime but to carry out a public policing function with the support of and in consultation with the local community (Manning 1978). As such, section 17.1 of the Act states that the PCC, when carrying out any statutory functions, 'must have regard to the views of people in the body's area about policing in that area'. More particularly, section 14 (amending s.96 of the Police Act 1996) holds that 'arrangements shall be made for each police area for obtaining the views of people in that area about matters concerning the policing of the area, and their co-operation with the police in preventing crime in that area and for obtaining the views of victims of crime in that area about matters concerning the policing of the area'. Making explicit reference to police and crime plans, it states that such arrangements must include arrangements for obtaining 'the views of the people in that police area, and the views of the victims of crime in that area, on that plan' before it is published. The commissioner must also consult the relevant chief constable and the Police and Crime Panel. 
The duty to ascertain the views of the people also extends to the chief constables. Pursuant to section 34 of the Act, the chief officer of police 'must make arrangements for obtaining the views of persons within each neighbourhood in the relevant police area about crime and disorder in that neighbourhood'. He or she must also 'make arrangements for providing persons within each neighbourhood in the relevant police area with information about policing in that neighbourhood (including information about how policing in that neighbourhood is aimed at dealing with crime and disorder there)'. Arrangements should include 'the holding in each neighbourhood of regular meetings between persons within that neighbourhood, and police officers with responsibility for supervising or carrying out policing in that neighbourhood ... it is for a chief officer of police to determine what the neighbourhoods are in the relevant police area'.

These provisions clearly expressed the Government's political 'orthodoxy' that police forces and police authorities had lost sight of the community-oriented function of public policing and that the appointment of a directly-elected individual to hold each police force to account was fundamentally necessary. The Home Secretary defended the policy before the Home Affairs Committee, stating that the police had become 'disconnected from the communities they serve', 'bogged down by bureaucracy' and answerable 'to distant politicians' (HAC 2010, p.3). However, it must be recognised that this political orthodoxy was far from new. Since the 1970s, it has been widely accepted that police forces have a tendency to underappreciate the individual and collective senses of insecurity within the community by attaching too much weight to insular policing expertise (Goldstein 1990). Anti-social behaviour, for example, was one area which was frequently under-appreciated or poorly understood by police forces. Numerous dramaturgical police studies, not least Wilson and Kelling's (1982) 'broken windows' theory, showed that police forces which rely almost exclusively on internal professional expertise and often inaccurate and incomplete statistical indicators can end up under-policing (or over-policing) problem neighbourhoods.

In contrast, community-oriented policing theory held that civilians should be able to ask the police force to amend the conduct of its police officers, the deployment of its resources and its strategic and tactical policies in order to address community needs, wants, concerns and complaints (Manning 1978). Commentators argued that communities should be able to regulate the exercise of police discretion by encouraging police officers to narrow their exercise of discretion in areas of growing community concern or by applying a wider application of discretion in areas where hard policing tactics were perceived to be unfair or counterproductive. This degree of community input, Klockars (1985) argued, was crucial for validating and legitimating the exercise of police discretion, which cannot be found in legal statutes. More conceptually, the theory aimed to realise the ideal of 'policing by consent' and the traditional Peelian principle that the 'police are the public and the public are the police' in a pragmatic way. Police forces who try to police by consent should ultimately be able to point to local community consultation to explain, substantiate, validate and shape their strategies, tactics and conduct (Manning 1978). Police-community partnership should also enable civilians to become more vigilant about their own personal security and help them to identify and report anti-social behaviour, harassment, domestic violence, honour-based violence and extremist behaviour witnessed in familial, neighbourhood or business settings (Bayley and Shearing 1996). Information gathering in this way through community engagement has long been central to conceptions of 'intelligence-led policing', formulations of risk and reassurance policing within constitutional democracies (Fielding and Innes 2006). The Home Affairs Committee clearly reflected this ethos when it stated that PCCs must ' ...communicate with their electorate about all the threats and risks they are facing so that voters can make 
evidence-based decisions about local policing priorities. The quality of data is crucial in this context: both to inform the public in the first place and to help Police and Crime Commissioners to reflect a true picture of the needs of the communities they serve ...' (HAC 2010, p.8-9).

It is also widely appreciated that the realisation of community-oriented policing is far from simple. One of the most complex aspects of the theory itself is the fractured concept of community. Modern approaches to 'multiculturalism' assumes that society, and its inherent communities, should be able to accommodate the uniqueness and differences associated with multiple cultures. Loader and Mulcahy (2003, p320-325) remark that late or post-modernity demands a 'cosmopolitan policing culture'; one where police forces must be tolerant and sensitive to differing views, value orientations and approaches to the cultural, political and economic values espoused by multiple cultures which are constantly in flux. Brogden and Nijhar (2005) advocate that the police need to treat each and every individual within a neighbourhood as valued and distinctive service users, each with their own distinctive crime problems and resident concerns which fluctuate over time. The constant involvement of diverse communities in the policing policy process is considered to be vital to ensure the continued legitimacy of the public policing in a post-modern world and to future claims of 'policing by consent' (Jackson et al 2012). Another complication is that communityorientated policing demands a relationship of partnership or 'inter-dependence' not just between civilians and the police, but between the police and other agencies of civil society as well (Neyroud and Beckley 2011). Infrastructural improvements, such as the improvement of street lights, zoning and residential planning, can for instance have an effect on crime rates (Goldstein 1990). Educational and employment opportunities can also be enhanced through regulation and financial innovation, particularly for the socially deprived. Loader and Sparks describe this as a form of 'multi-institutional governance' which facilitates the plural 'coproduction’ of order and security (Loader and Sparks 2002, p.87-89).

The PCC construct was far from the first model to attempt to realise the ideal of communityoriented policing and overcome these inherent obstacles. The creation of Police Authorities pursuant to the Police Act 1964, the establishment of Crime and Disorder Reduction Partnerships (CDRP) (now known as Community Safety Partnerships) under the Crime and Disorder Act 1998, and the introduction of the 'arrangements for obtaining the views of the community on policing' in the Police Act 1996 (s.96) are a selection of the initiatives introduced by various governments. The spirit of community-oriented policing is particularly well reflected in the popular re-labelling of police forces as police 'services', which positions the police organisation as a service designed specifically to meet the demand of its customers. The Police Reform and Social Responsibility Act 2011 placed clear duties on the PCC and the chief constables to engage in community consultation and the Police and Crime Plan was clearly the primary tool in the toolbox.

\section{The Police and Crime Plan: a mechanism of 'police accountability'}

The Police and Crime Plan is not only the primary tool used to capture the ethos of community-oriented policing but it is also one of the primary tools available to the PCC to hold the chief constable to account. The very first section of the 2011 Act requires each PCC to 'secure the maintenance of the police force for that area, and secure that the police force is efficient and effective ... [and to] hold the relevant chief constable to account for the exercise of the functions of the chief constable, and the functions of persons under the direction and control of the chief constable'. Most importantly, section 1.8a explicitly states that the PCC 
'must, in particular, hold the chief constable to account for the exercise of the duty ... to have regard to [the] police and crime plan'. Interpreting legal nuances in the section, the Home Affairs Committee explained that the use of the term 'effectiveness' in section 1 denoted the ability to deliver the police and crime plan, whereas 'efficiency' meant delivering the plan within the parameters of the force budget (HAC 2016, p.7). In addition to the delivery of the police and crime plan, the chief constable was also accountable for delivering a list of additional duties which communities and their representatives might reasonably expect and demand. These included: having regard to strategic policing requirements and codes of practice issued by the Home Secretary; the effectiveness and efficiency of the chief constable's arrangements for collaborative working, engagement with local people and value for money; and the exercise of duties relating to equality and diversity, the safeguarding of children and the promotion of child welfare. In practice, the PCCs were expected to focus on the 'role of setting strategic direction, and providing support, political direction and guidance' to the police force by way of the Police and Crime Plan and, crucially, that they would not 'fetter the operational independence of the police force and the chief constable' who would independently control operations on a day to day basis (ibid, p.12).

The centrality and importance of the Police and Crime Plan was not misunderstood by the first cohort of PCCs. The PCC for Leicestershire told the Home Affairs Committee that if his chief constable was asked to define his job in one sentence, he would say that "I deliver the Police and Crime Plan" (ibid, p.7). The Police and Crime Plan was clearly central to "a deal where the public are in control" (HAC 2010, p.8-9). Another PCC told the Home Affairs Committee that 'the only circumstances in which he would have considered using his powers of dismissal was if the chief constable had "strayed from the Police and Crime Plan" which would mean "the force is not doing the job we are expecting it to do" (ibid, p.13).

\section{Inside the Police and Crime Plan}

Section 7 of the 2011 Act requires that each plan establish the 'police and crime objectives' for crime and disorder reduction in that area; 'the policing of the police area' which the chief officer of police is to provide; and the 'means by which the chief officer of police's performance will be measured', amongst other things. Section 11.3 also provides that a PCC 'must publish the information ... to enable the persons who live in the body's area to assess ... the performance of the relevant chief officer of police in exercising the chief officer's functions'. The contents of the Police and Crime Plans for Greater Manchester, the West Midlands and the London Metropolitan area, would clearly indicate that PCCs are embracing the ethos of community-oriented policing. The Police and Crime Plan for Greater Manchester for 2016/17, for example, states that the priority of the PCC is 'to seek and reflect the views of the public and particularly victims of crime in setting policing priorities and holding the chief constable to account for the performance of the force' (2016, p.21). The PCC promises to investigate whether 'local policing and other public services operate in a way that is relevant to local communities, with an understanding of their needs and concerns'; whether the force is 'intervening early to tackle root causes of local problems'; and whether the force has 'done its utmost to provide good customer care and levels of service' (ibid, p.30-33). The plans for the West Midlands and Greater London use similar language throughout. The plan for the West Midlands (2015, p.8) promises that communities will be put 'first', while the London Mayor's Office for Policing and Crime (MOPAC) promises to greatly 'enhance' neighbourhood policing (2013, p.23). 
Moving from the general to the particular, the police and crime plans typically categorise the key objectives under a number of broad community-oriented themes. The West Midlands PCC employed six themes in 2015/16 which included: increasing public confidence/ pride in the police; creating stronger, safer, more prosperous communities; protecting people from harm; making better use of people and resources; creating a new era in policing; and responding to national threats. The PCC for Greater Manchester also used six, somewhat similar, themes in 2016/17. These included: tackling crime and anti-social behaviour; putting victims at the centre; protecting vulnerable people; dealing with terrorism, serious organised crime and maintaining public safety; investing in and delivering high-quality policing services; and building and strengthening partnerships. In turn, the Mayor of London demanded a blanket improvement of 20\% across six general areas for the period 2013 - 2016 which included: reducing neighbourhood crimes, reducing costs, improving confidence, reducing delays in the criminal justice system, increasing the use of community sentences, and reducing reoffending by young people leaving custody. These themes are little more than headings so they are understandably vague. The expectation is that more practical, real-life issues would be captured, explained and addressed under the various headings within the police and crime plans.

With a view to addressing the considerably vague and often overlapping themes, the West Midlands PCC established a number of key 'deliverables' for his chief constable to achieve in 2015/16. The chief constable was required to 'increase public confidence' in the police (which the plan denoted was at 82\%), 'increase satisfaction' with services in relation to crime and anti-social behaviour, increase reporting of 'hidden' crimes such as domestic violence, child abuse, hate crime and honour-based violence; 'increase accuracy' of crime recording; reduce 'crime rates' in respect to the burglary of dwellings, violent crime, organised crime and business crime; and reduce the number of police conduct complaints. Taking a slightly more ambiguous approach, the PCC for Greater Manchester (2016, p.14-20) required his chief constable to 'prevent, solve and reduce crime and anti-social behaviour' by focusing on the specific offences and offenders that cause the greatest harm to communities and individuals; 'identify and address the causes of dissatisfaction and complaint with services received by victims and witnesses'; 'build confidence amongst victims and witnesses'; 'ensure that the response to civil emergencies and major events is comprehensive, coordinated and effective'; and 'that malpractice is dealt with robustly and complaints are dealt with sensitively and transparently' amongst a number of other goals. In London, the Police and Crime Plan (MOPAC, 2013) was used as more of a blunt instrument, demanding a $20 \%$ reduction in key neighbourhood crimes such as burglary, robbery, criminal damage and violence with injury (250,000 fewer crimes); a 20\% reduction in costs ( $£ 500 \mathrm{~m}$ savings); a $20 \%$ increase in confidence in the police (up to 75\%); a 20\% reduction in delays in the criminal justice system; a 20\% increase in compliance with community sentences; and a $20 \%$ reduction in reoffending by young people leaving custody by 2016. The crude targets of $20 \%$ are potentially symptomatic of the fact that, in practice, the role of the PCC is carried out by a Deputy Mayor for Policing and Crime (DMPC) who is not directly-elected by constituent communities and therefore somewhat removed from the coalface of grass-roots problems. However, the Mayor, who is directly-elected, is required to hold to account his or her appointed Deputy in respect to the delivery of the Police and Crime Plan so the targets should arguably be reflective of constituent community issues and concerns and ultimately legitimised through the election process.

Surprisingly, the Police and Crime Plans do not get much more specific than this. Although PCCs typically arrange daily meetings or calls with their chief constables and receive 
summaries of crime occurrences and case progression, the plans contain no real mention of specific crimes or cases which are inflicting particular neighbourhoods. Reference is made in the plans for Greater Manchester and the West Midlands to 'Local Policing and Crime Plans' which are developed in consultation with local authorities, but these appear to constitute little more than a restatement of the broader objectives. A selection of its 'deliverables' set out in the Local Policing Plan for Birmingham (2013, p.2-7) include the following: 'we will reduce burglary by focusing on the areas suffering from this crime, ensuring offenders are targeted and managed to reduce offending ... we will ensure that our communities are satisfied with the service they receive when they report anti-social behaviour ... we will target criminal gangs operating in central Birmingham ... we will increase our arrests for drug dealing and seize criminal assets'. Like the PCC's broader plan, these objectives lack specific details to guide police officers or members of the public. They are almost entirely devoid of specific, workable information. The deliverables and objectives are not even close to being clear enough so that they can be broken down into tasks which are achievable and delegated to units who are capable of achieving them.

More broadly, the police and crime plans do not contain crime reports, crime maps or threat assessments of local crime, terrorism, organised crime or cyber-crime. The benchmarks for public confidence, satisfaction, reporting, recording, complaint and inter-agency collaboration around victims and mental health are largely generic. Not only are the PCCs intentions vague but almost no attempt is made to translate aspirations into actions, methods or means. The West Midlands Plan claims that the neighbourhood policing team emphasise 'consistency', 'continuity', 'engagement', 'communication', 'visibility', 'community-led initiatives', 'neighbourhood watch' and 'developing specialist staff' but without the accompaniment of specific details these promises are little more than value-free rhetorical clichés. Taking a similarly rudimentary approach, the Plan for London (2013) states that dedicated, named Neighbourhood Inspectors will be accountable for dealing with crime and disorder such as antisocial behaviour, robbery and burglary. It promises that every borough, 'will continue to have a team who specialise in responding to emergency calls and provide a high-quality service at that first contact with police' (ibid, p.23). These are nothing more than elementary restatements of the most basic of police activities and functions. Moreover, the Plans make no mention of cases pertaining to police deviance or corruption. This is despite the fact that both the West Midlands and Greater Manchester police were found by the IPCC (2014) to be mishandling 8 out of 10 cases relating to allegations of racial discrimination as recently as 2014. Bland statements such as 'we will ... continue our review of Force management and leadership' do not indicate whether and to what extent these problems are being rectified (WMPCC 2015, p.24).

In terms of inter-agency collaboration, although the levels of funding provided to each local policing and crime board and the grants awarded to Community Safety Partnerships and collaborative initiatives were typically outlined in the Plans, there was no precise indication of the performance benchmarks which would measure the effectiveness of these initiatives. It was far from clear whether the collaborative inter-agency initiatives, which often involved rehabilitation initiatives, probation, offender management, mental health and victims' services were even geared towards specific community problems. This is despite the fact that the Stevens Commission (2013) concluded that the proliferation of collaborative agencies appeared to be contributing to a disjointed field where progress is slow and actions are not being followed up as priorities and memberships change. Quite damningly, the Commission found that there was a tacit acceptance by participants of the inherent value of partnerships in the absence of a fulsome assessment of outcomes and limited evidence of their impact on 
community crime and disorder problems. In 2014, HMIC had also reported that, although PCCs continue to prioritise inter-agency working and collaboration pursuant to Section 10 of the 2011 Act, nearly half of the police forces in England and Wales expected five per cent or less of their business to be delivered through collaboration in 2014-15 (HAC 2014). The ambiguity of the police and crime plans in the presence of considerable criticism around the substance and nature of the inherent aims, objectives and evidence-based is surprising to say the least.

Although section 7 of the 2011 Act requires that each plan establish the 'means by which the chief officer of police's performance will be measured' and section 11.3 provides that the plans should '...enable the persons who live in the body's area to assess ... the performance of the relevant chief officer of police in exercising the chief officer's functions', it would appear that commissioners currently enjoy a remarkably wide latitude in their interpretation of these provisions. Instead of establishing clear 'means' which can be measured and assessed, PCCs have done little other than creatively wrap up these basic requirements within a number of ambiguous themes and rhetorical clichés. The absence of specific, tangible actions and consideration appears to reflect a lack of seriousness of PCCs towards their statutory responsibilities and community-oriented policing more broadly.

In defence of PCCs, the attraction in setting broad, ambiguous targets is partly attributable to the well-known hazards of setting targets for crime reduction. HMIC's all-force annual report for 2012/13 found that the performance culture embedded in the 1990s where targets were set at force and national level created 'perverse incentives to under or misreport crime' (HMIC 2014, p112). In particular, Police Recorded Crime (PRC) statistics were seen to be so susceptible to manipulation or 'gaming' that in January 2014 the UK Statistics Authority stripped the PRC statistics of their designation as National Statistics (HAC, 2014). As a result, one PCC told the Home Affairs Committee that one of his first acts in office was to do away with numerical targets (ibid).

Nevertheless, section 11.3 of the 2011 Act would indicate that the perusal of a Police and Crime Plan should provide the reader, whether a civilian or a police officer, with a reasonable understanding of the nature of local crime occurrences, the emerging modus operandi of local criminals and the steps being taken by the police force to address them. In the spirit of community-oriented policing, civilians should be able to use the plans to not only hold the police to account to particular objectives but to become more vigilant about particular crime problems so that they can actively participate in the ethos of partnership. As Adlam (2003) conveys, clarity in strategic police planning should include not only the police force's social mission or social philosophy, such as the general tackling of public disorder and crime, but the inherent objectives and ethos which guide and shape the form and style of interpersonal encounters. Unfortunately, the police and crime plans would appear to be little more than a statement of the PCCs social philosophy rather than a statement of clear objectives which would guide and shape the form and style of police activities and civilian interactions.

\section{The extent of community 'input'}

On the subject of social philosophy, there is limited evidence within the police and crime plans to suggest that the 'deliverables' are actually based upon community needs and wants. The plans make no clear attempt to pinpoint the concerns of particular neighbourhoods or reconcile a cross-section of views. When challenged by the Home Affairs Committee (2016), various PCCs admitted that they simply do not have the resources to communicate directly 
and effectively with the public. The Police and Crime Plan for London (2013, p.18-19), for example, stated that it was premised by and large on a town hall meeting in each of the 32 city boroughs which involved no more than 3000 people as well as an online survey, focus groups, forums and 'hundreds of written responses and ... scores of community groups'. Moreover, MOPAC (2015) reported that it had received only 2470 enquiries from members of the public between April 2014 and April 2015. With a population of over eight million people, the involvement of only a few thousand people and hundreds of written responses does not appear to amount to a representative sample or significant engagement in community consultation. A palpable lack of public interest and engagement is particularly evident in the fact that the PCC for the West Midlands (2015b) reported that only one and a half thousand people, in an area of almost 3 million people, subscribed to his regular newsletters and little more than 1,000 people had contacted his office the previous year to raise their policing and community safety issues. Websites, face-to-face meetings, conferences, summits, youth commissions, newsletters, live webcasts, social media, mobile apps, stalls at shopping centres, attending local council meetings and mobile police contact points were variously used by the three PCCs in an attempt to gauge concerns (HAC 2016).

Caless and Owens are particularly critical of the attempts of PCCs at grassroots consultation. They found that PCCs who relentlessly engage in public encounters, whether face to face or through social media, do so 'merely to have more people recognise them and understand what they do, if they are lucky' (2016, p.148). The ambiguous nature of the police and crime plans appears to hide the question of whether and to what extent systematic translation of community needs and wants is actually taking place at all. Lister and Rowe (2014) similarly found that '...there are recurring questions over how the results of such consultations are interpreted and thereafter translated into practice'. Furthermore, Caless and Owens (2016, p.137) argue that the impact of social media work is particularly questionable since none of the PCCs they interviewed had considered 'surveying the impact of their social messaging ....and whether or not the PCCs social messaging is reaching large numbers of young people'. They found that, in reality, serious commentary about society, the fear of crime and personal unease hardly figure in social media largely because the purpose of the social messaging site was about 'having fun and unwinding' (ibid, p.147). They concluded that the PCCs 'conviction that this is worth it sometimes borders on the desperate...' (ibid, p.148).

The lack of proactive public engagement on the part of PCCs is lamentable considering the fact that voluminous academic research indicates that it is not unusual for some communities to be systemically averse to community-police dialogue out of hostility and distrust caused by prolonged periods of over-policing, abusive practices, perceived prejudices and generational neglect (Scarman 1981). Unfortunately, the Police Reform and Social Responsibility Act 2011 is silent on the forms, frequency and methods of community-engagement which PCCs should employ. Whether and to what extent a PCC engages in wide reaching consultation remains largely a discretionary decision, unique to each individual PCC. In the absence of a more structured apparatus, it would appear that section 14 which requires the PCC to obtain 'the views of people in that area about matters concerning the policing of the area ... and the views of victims of crime in that area' is only being paid lip-service. Lister and Rowe (2015) found that some PCCs will engage in a measure of community consultation 'rather hurriedly' and only when they are required to do 'shortly after coming into office (i.e. once every four years)'. Similarly, the Stevens Commission (2013, p.81) found that 'there is little evidence to indicate ... that PCCs are engaging successfully with diverse communities across their constituencies' at all. The contrast in personality and approach in different PCCs has been described as a 'Jekyll and Hyde' complex (Caless and Owens 2016, p.77). 
The indicative result is that there does not appear to be sufficient community input which could lead to commensurate community-oriented outputs. The apparatus appears wholly inadequate. Communities are having a negligible effect on the shape and form of police policies and priorities. The participatory and deliberative conception of policing which was initially hoped for appears to have been replaced by the tendency of PCCs' to employ language and rhetoric within their plans which presents a politically desirable image of discursive policing but without the substance (Loader and Mulcahy 2003). Vague mission statements like 'we serve our community' and 'we listen to our citizens', which were traditionally employed by chief officers to the frustrations of civilians and police authorities alike, have simply become the preserve of a newer and even more political vehicle. The ability of PCCs to make 'quick decisions', which appears to be prized by police officers in particular, reflects a reliance on individualistic problem-solving skills rather than a reflection of community expression (Caless and Owens, 2016, p.86).

The clearest problem to most commentators is that, no matter how proactive a PCC is, one individual simply cannot continuously gauge the concerns of each and every individual in a constituency, which sometimes have a population well in excess of two million people spread across large geographical areas. One PCC who was interviewed by Caless and Owens (2016, p35) told them that 'I just need to be persuaded that you can vest all that power in a single individual and still represent everyone. From the experience of the last two years I don't think it's possible to do or have it all'. Another PCC admitted that 'I could spend all my time just meeting people and it still wouldn't be more than a quarter of the electorate' (ibid, p.145). The Stevens Commission (2013) similarly concluded that it is not conducive or effective to have one person singularly responsible for democratic police governance across an area of millions of inhabitants.

Another aspect of the model, which the Stevens Commission (2013, p.82) felt exposed 'the limits' of the single individual model of police governance, was the fact that some PCCs have established a committee of diverse representatives who have been delegated the responsibility to engage in community-consultation within constituent local authority areas. For instance, the members of a Strategic Policing and Crime Board, established by the West Midlands PCC, are expected to engage with local people, liaise with partnering agencies and hold meetings in public on a quarterly basis in order to measure performance in the local area against objectives in the Police and Crime Plan (WMPCC, 2015a). However, there is limited evidence to suggest that the members of the Strategic Board actively engage in widespread community consultation. It was not unusual for the minutes of Board meetings (2016) to record that 'there were no questions from the public or petitions received'.

\section{Using the plans to hold the Chief Constable to account}

Sections 1.8a of the 2011 Act explicitly states that the PCC 'must, in particular, hold the chief constable to account for the exercise of the duty ... to have regard to [the] police and crime plan'. The ambiguous nature of the police and crime plans clearly means that it is quite difficult for chief constables to turn the far-reaching objectives into manageable actions which are capable of being realised by designated police officers. Unfortunately, it would appear that the more ambiguous the police and crime plan, the less secure the chief constables job is. The setting of largely unachievable targets means that PCCs will readily be able to find a reason for dismissing a chief constable if he or she chooses. Section 38(3) of the 2011 Act which provides that 'the police and crime commissioner for a police area may call upon 
the chief constable of the police force for that area to resign or retire', is largely silent on the grounds upon which a PCC can wield this power. In the absence of clear checks and balances, the apparent omnipotence creates a degree of unfairness as it allows PCCs to dismiss chief constables who 'underperform' when measured against unrealistic aims in the police and crime plans. Conversely, PCCs can also use the ambiguity of the police and crime plans to protect chief constables who are favourable to them. By avoiding clear evidencebased objectives in the police and crime plans, PCCs can allow chief constables to largely run their forces as they see fit. By playing down aspects of poor performance or police deviance, the PCC can potentially deflect unwanted media and public scrutiny away from any police failures. Working together to creatively present a fictitious account of police performance, both PCCs and their chief constables can 'protect' the 'good image' of the force, and by extension, the job security of the former. The Leicestershire PCC, for example, informed the Home Affairs Committee (2016, p.12) that he and his PCC were "friends", while the Derbyshire PCC, described his relationship with his Chief Constable as "excellent" and that there had "never been any major disagreements on any policy area at all."

If the courting of the loyalty of chief constables is an implicit factor behind the ambiguity of the police and crime plans, it appears to be explicitly evident within the process of chief officer selection. The Home Affairs Committee found that between April and October 2015, only 11 applications were submitted for five vacant Chief Constable positions advertised across England and Wales (ibid, p.13). Two of the posts attracted single applications. Of most concern was the fact that all of the appointments were subsequently awarded to the incumbent Deputy Chief Constable. A similar issue arose within the competitions for the rank of deputy constable, where only 17 applications were received for eight posts. Reflecting upon the situation, the Chief Inspector of HMIC told the Home Affairs Committee that PCCs are:

'...having a "chilling effect" on the most talented police officers applying for the most senior posts ... [that] there appears to be an assumption in the highest ranks of the police that in some cases PCCs may already have made up their minds. And, therefore, why put yourself through a selection process and show your existing force that you are looking for another job if the chances are very high that the existing deputy is going to get it anyway' (ibid, p14).

The overt degree of cronyism and the 'covert' ambiguity of the police and crime plans is remarkable in light of the fact that one of the most criticized elements in the history of policing has been the quality of its leaders and managers (Punch, 2009). Academic research has long pointed to the fact that, although the raison d'être of a hierarchical police organisation was to ensure a disciplined police force, free of deviant and corrupt behaviour, its leaders and managers tend to lean towards the pervasive tendencies of 'transactional leadership' (Adlam and Villiers 2003). Transactional leadership styles typically involve police managers prioritising the self-interests of both the leader and the subordinate over and above the public interest or the moral development of either party, which often boils down to commanding officers generating loyalty from subordinates by avoiding punishment for poor performance and malpractice (Bittner 1970). Giving a measure of credence to the perception, HMIC indicated in the Annual Assessment of Policing in England and Wales for 2015 that some chief officers continue to "disregard what is required of them" and were not doing enough to adopt consistent standards of leadership and behaviour, share best practice and work collaboratively. The prevalence of transactional loyalty at the highest levels of police governance is particularly well exemplified in the following statement by one particular PCC 
who was interviewed by Caless and Owens (2016, p80): '[I] went straight to sergeants and constables and met more than 700 of them in the first two months. I fixed lots of small niggles - ranging from poor equipment to badly organised shifts - so the front line eventually said "Bloody hell, we can work with this bloke" and they backed me'. Instead of prizing the loyalty of their police chiefs, PCCs should be committed to providing a high quality service to the community, supporting staff to achieve this, challenging poor behaviour and rewarding achievement by using the police and crime plan as a central measurement in the first instance.

\section{Measuring the success of the Police and Crime Plan}

Section 12 of the Police Reform and Social Responsibility Act 2011 provides that each PCC 'must produce a report (an "annual report") on the exercise of the body's functions in each financial year, and the progress which has been made in the financial year in meeting the police and crime objectives in the body's police and crime plan'. The requirement to publish such information also falls within the parameters of section 11.3 of the Act which states that a PCC 'must publish the information ... to enable the persons who live in the body's area to assess ... the performance of the relevant chief officer of police in exercising the chief officer's functions'. Unfortunately, the annual reports published by the three PCCs shed little more light on the activities and successes of the office of PCC or the respective police force than the police and crime plans themselves. For example, the West Midlands PCC (2015) reported that public place violence with injury, had increased by almost 11 per cent $(1,048$ offences) compared to 2013-14. No explanation was provided for this increase and no immediate form of remedial action was identifiable. Comparably, MOPAC's Annual Report (2015, p.8) stated that burglary was down $24 \%$ but violence with injury had 'seen an increase'. Although some effort was taken to explain the fall in burglary, no attempt was made to explain the increase in violence.

In respect to public confidence, the Annual Report for London (2015, p10) stated that confidence in the police 'has risen, but is not on track to meet the $75 \%$ target'. Similarly, no attempt was made to explain any potential reasons behind the lack of confidence expressed by members of the public. In comparison, the Greater Manchester Police (2013) reported that $91 \%$ of residents believed the police do a good or excellent job and that $84 \%$ of victims were completely/very/fairly satisfied with overall service. Again, no attempt was made to explain why upwards of $15 \%$ of the population did not have confidence in the police. Similarly, the West Midlands Police (2015) reported that public confidence was at $82 \%$ and satisfaction with service was at $82.8 \%$ in 2015 but no attempt was made to explain the substance of these statistics. Moreover, no attempt was made to critically analyse the content and accuracy of the figures.

Much like the police and crime plans, significant portions of the Annual Reports were filled with vague, rhetorical statements. The current Annual Report for the PCC for Greater Manchester (2016, p.10-28) states for instance that 'I have been working with partners to develop a more responsive service for victims and witnesses, plugging any gaps and ensuring the needs of victims are central to everything we do'; 'officers are now more visible in local communities'; and 'we are better safeguarding vulnerable children and young people, targeting those who prey on them'. Most of the tangible 'successes' essentially involved bringing together police and other agencies to form commissions or collaborative units, as well as the launch of complementary informational websites. The impact and added-value of these initiatives was not addressed. The nature and extent of police complaints against the force were also unexplored. MOPAC’s Annual Report (2015, p.31), for instance, indicated 
that the total number of public complaint cases had decreased in the past year but complaints from other police staff or officers had risen. No details were provided about the nature or severity of these complaints and why complaints from within the police organisation had risen.

The ad hoc 'performance reports' published by the PCC for Greater Manchester between the annual reporting periods were similarly vacuous. One such report from November 2013 contained statements such as: 'I have spent much of my time speaking and liaising with members of the public'; 'I have undertaken considerable consultation with both victims of domestic abuse and those agencies who deal with individuals who experience domestic abuse'; and 'the result has been the development of an agreed approach to joint working' (2013, p.1-7). Rhetoric such as this sounds comforting but without further detail, it does not indicate whether any progress has been made beyond the holding of initial discussions. Similarly, the reports on Local Police and Crime Plans for constituent areas such as Trafford and Salford amounted to little more than a vague outline of the number and nature of meetings attended in the particular constituencies. At a meeting in Salford, for example, the PCC (2013b, p.2-5) reported that 'issues discussed included reductions in crime, the challenges presented by the budget cuts, working in partnership to tackle the causes of crime, the crucial role of neighbourhood policing and PCSOs...' amongst other issues. If some clear, specific information was provided at these meetings, it was not reflected in the subsequent report.

Although the reports of the PCC for Greater Manchester were relatively non-descript and laden with rhetoric and clichés, the report of the Chief Constable to the Commissioner for Greater Manchester for 2013 told quite a different story to the PCC's report of the same year. The Chief Constable's report was far more informative, specific and unpolished in its presentation than that of the PCC. The Chief Constable (2013, p.4-9) reported, amongst other things, that in 2013 there had been a 'significant' 19\% increase in crimes of theft from the person; a 'significant' increase of $18 \%$ in sexual offences; and a 'significant' increase of $10 \%$ in incidents of anti-social behaviour. The increases, although considered 'significant' by the chief constable, were not explained or treated in the PCC's own reports or plans. Moreover, the PCC did not draw attention to the fact that only 23\% of victim-based crimes had been solved in the previous 12 months (ibid).

In direct contrast to the PCCs approach, the Chief Constable made an attempt to explain the nature of some of the crimes and the subsequent strategies pursued. The crimes of theft from the person, he noted, commonly involved the theft of smartphones (ibid). To address this issue, the police force had launched a specific operation to deploy mobile advertisements in hotspot areas and venues in order to disrupt the methods used by offenders to steal and re-sell mobile phones. On the subject of anti-social behaviour, the Chief Constable indicated that the $10 \%$ increase in incidents had been influenced by the reduction or discontinuation of services provided by other organisations to combat begging and vagrancy as well as an increase in the number of malicious or nuisance communications perpetrated via social media. Turning to the subject of organised crime, the Chief Constable indicated that there were more than 160 known organised crime groups in Greater Manchester. To combat these groups, he reported that, in collaboration with HMRC, the Department for Work and Pensions and the National Crime Agency amongst others, the force had made over 76 arrests for offences of money laundering, possession of firearms, robbery and drugs possession. The force had also seized $£ 32,700$ under the Proceeds of Crime Act, fifty tonnes of counterfeit goods worth £2million, class $A$ and $B$ drugs worth $£ 455,000$ and twelve stolen vehicles (ibid). In comparison to the 
Chief Constable's report, the PCCs plans and reports were considerably uninformative and arguably misleading.

The misleading nature of the police and crime plans and the associated annual reports is perhaps epitomised by the following example. The West Midlands PCC (2015b) reported that public place violence with injury had increased by almost 11 percent (1,048 offences) compared to 2013-14. Following this, the West Midlands Police and Crime Plan for 2015/16 demanded a reduction in violent crime and burglary. Subsequently, in June 2016 the PCC's Strategic Board for Crime and Policing reported that public place violence was 'stable' at an average of 1000 crimes per month respectively. The reduction was negligible and the 11 percent increase recorded in 2014 had not been reversed. Nevertheless, the use of the term 'stable' suggested that this was a positive outcome. At the same time, the number of burglaries had seen 'a step change up' and, more broadly, average monthly levels of total recorded crime had witnessed 'significant step changes up' to a new monthly average of 15,538 crimes. Moreover, no attempt was made to explain why the 'step change up' occurred, whether 'stable' crime occurrences were acceptable and what the Chief Constable or the PCC was planning to do about it.

Not only was the rhetoric around crime reduction misleading but the PCC for the West Midlands (2015a, p18-22) had also demanded the police to 'increase public confidence' and to 'increase satisfaction' with services in relation to crime and anti-social behaviour for 2016. The PCC's Strategic Policing and Crime Board (2016) subsequently reported that there had actually been 'no significant changes' to public confidence since October 2010 and that 'levels have been particularly stable since June 2014'. Yet the same report showed that there were in fact wide disparities in public confidence and fear of crime across the force area. The Board stated that 'confidence in local policing on individual Local Policing Units (LPU) ranges from $87.4 \%$ in Walsall to $77.3 \%$ in Birmingham East ... [and] Wolverhampton saw a drop ... to $81.7 \%$, from $87.9 \% 6$ months previously' (ibid). Similarly, in regards to fear of crime, it was found to be highest in Walsall (21.3\%) and lowest in Solihull (12.2\%). The average in Coventry was $19 \%$ in 2015 , up from $13 \%$ in 2012 . No attempt was made to explain why the rates of 'public confidence' and the 'fear of crime' statistics were higher in some local authority areas than others. The Board did not address whether and to what extent this is down to the work of the PCC or particular police activities. In fact, it admitted that 'there is no data available about which crimes people are more fearful of' (ibid). The wide disparities, the lack of improvement over time and the absence of investigation serves to fundamentally discredit the PCCs claims to community-oriented policing and 'effective' policing.

\section{Using the Police and Crime Plans for 'image work'}

It would appear that the traditional quantitative objectives of reducing reported crime rates, increasing clearance rates and realising faster response times, which were subject to so much manipulation and 'gaming' in past decades, have been replaced by similarly artificial qualitative objectives which lend themselves to manipulation and gaming to an even greater extent. The prevailing situation arguably enables PCCs to prioritise deliverables which can be manipulated to serve the interests of 'public relations' over and above 'community relations'. 'Public relations' in this context involves the promotion of a superficial public image of policing whereas 'community relations' involve learning about the needs of minority groups and adapting police procedures to provide a reassuring police service for all (Banton 1973). The ease with which a PCC can employ rhetorical language means that police and crime 
plans can be employed as an even bigger shield for manipulating the reporting process than the traditional quantitative measurements. Using terms such as 'stable' as a euphemism, PCCs can apparently avoid addressing rises in crime rates and drops in public confidence once a positive 'spin' can be found.

The interviews carried out by Caless and Owens (2016) indicate that PCCs are cognisant of the power of this 'image work'. They found that the desire of the PCC to cultivate a positive image of the police by putting a positive spin on policing activities was a deliberate strategy. One PCC told them that “...thinly attended meetings in cold village community centres don't do it for me. I'd rather be filmed talking to someone in a shopping centre or in a town square. Better visually and better visually and better in terms of media attention” (ibid, p.145). One chief officer told them that 'I don't see much of her [the PCC] at public events unless they're on telly ...' (ibid, p.151). Indicating that the rhetorical nature of the police and crime plan is reproduced through the medium of the media, one interviewee said that '.. what the audience doesn't see is that his [the PCC's] message is the same each time (I could certainly repeat it word-for-word): hold cops to account, reduce crime, increase and support neighbourhood teams, reassurance, cut anti-social behaviour, cope with budget cuts, prevent crime, care for the environment and the rest...' (ibid, p.152). Another chief officer added that the PCC 'seems to find it hard to step outside his restatement of the clichés that got him returned to office ... what he hasn't got across to the public is what he has actually achieved in any of his platforms' (ibid, p.203).

It is well established that 'image work' can play an important part in policing (Mawby 2002). The benefits of a good working relationship between the police and the media can mean widespread coverage of policing successes and a balanced treatment of negative stories. Caless and Owens laud the benefits of having a 'go-to person' who the media can approach for information about the police. They found that PCCs were 'quite adept at positive publicity, [and] courting the media...' (2016, p.2). The old police tactic of 'say nothing and deny everything' has been replaced by the ability of a clear leader to 'service the media' (ibid, p.126-133). One of the chief officers interviewed by them commented that the PCC 'charms them [the media], briefs them, has them in for drinks ... feeds them stories, suggests angles for a story ... even supplies pictures’ (ibid, p.131).

However, media work should by no means act as a replacement for community-oriented policing. As Mawby (2002) conveys, police forces should be image conscious and engage in image management but such 'image work' must be based on the ethical and effective conduct of its police officers during interactions and engagements with the public rather than a fictitious presentation of policing which is designed for public consumption. The presentation of a fictitious account of police performance and community attitudes in place of policecommunity partnership inevitably leads to perverse forms of police governance. Statements such as 'I represent the voice of the public', 'I am the voice of the people' and 'I represent all the people' can lead to the self-promotion of PCCs personal virtue ethics and political ideals. This can evolve into a form of omnipotence, absent of wider community consultation and representation. A degree of self-grandiosity amongst PCCs was identified by Lister and Rowe (2015), who examined the election statements of all 41 successful candidates and found that only $58.5 \%$ of the statements mentioned 'consultation with the public', which is one of their primary statutory responsibilities. They concluded that 'there was no evidence in the election statements of incoming PCCs that such a discussion was even anticipated’ (ibid). 
Rather than heralding a new era of explanatory accountability, it appears more likely that the 'communicative gap' which exists between the police and the communities they serve is widening (Loader and Mulcahy 2003). The dominance of the PCC's personality appears to recreate many of the problems associated with the professional police attitude of the 1970s. PCCs, like the chief officers before them, now appear to believe that they know what is best for the community without actually asking (Manning 1978). The ethos of communityoriented policing, which was developed in the 1970s to explicitly counteract the professional police mind-set, has spawned the very form of insular police governance that it was designed to counteract. The ethos of community-oriented policing, now in the custody of PCCs, appears to have once again become a 'semantic sponge', a value-free concept and an 'antidote for all ills which refers to everything but nothing at the same time' (Brogden and Nijhar 2005).

\section{Conclusion}

The sub-standard quality of the police and crime plans and the associated reports would indicate that PCCs are not effective managers, who can devise strategic plans and direct the organisations resources towards those objectives. Nor are they particularly good leaders, who can inspire police officers and members of the public to achieve clear objectives as a common mission. The experiment has been reduced, by the PCC themselves, to little more than a superficial public relations exercise which promotes or advertises an assumed degree of civic participation but without the substance. Although the PCC construct appeared to hold the promise of enhanced local democratic accountability, it has arguably been more successful in reinforcing the superficial, value-free notion of community-oriented policing. Comprehensive grass-roots consultation, local police activities and key statistics are not being reflected in the police and crime plans. The plans reflect the absence of widespread community consultation, systemic communication, planning and review. Rather than building respect through fairness and effectiveness, PCCs appear to be relying primarily on their positional power granted to them by statute to give policing the veneer of communityoriented policing, scrutiny and local democratic accountability rather than the substance.

Unfortunately, the election process does not hold much promise either. Although voter turnout has risen to 26\% in 2016 from 15.1\% in 2012, fewer female and BME candidates stood for election in 2016 (Casciani 2016). Although the Home Affairs Committee (2016, p.10) was of the opinion that a higher voter turnout 'would be a vindication of their establishment, and give them a clear mandate to continue developing their role', the lack of female, BME and independent candidates would appear to seriously undermine the legitimacy of the community oriented dimension of the PCC project at its very roots. Similarly, the much lauded improvements in public awareness are dubious. The Home Affairs Committee (2014) was informed that public awareness of PCCs was at 62\%, compared to 7\% for the Police Authorities they replaced, yet around the same time a Populus poll found that only 11\% of people could name their PCC (Stevens Commission 2013). A YouGov/ Times Poll at the time found that only 3\% of people surveyed thought that PCCs had made the police more effective and 63\% thought that the police had not changed in terms of being accountable (ibid). More recently, the Electoral Reform Society conducted a poll one week before the election in 2016 which found that nine in ten members of the public could not name their local police and crime commissioner (Perraudin 2016). Young people were found to be particularly bad at naming their PCC, with $1 \%$ of 18 to 24 year olds able to do so (ibid). One PCC described the "dearth of knowledge" amongst the general public about the basic function of PCCs in 2016 as "horrendous" (HAC 2016, p.9). 
Although, the Conservative Party continues to praise and promote the 'political orthodoxy' of PCCs and have made plans the Policing and Crime bill 2016 to extend the role of the PCC into areas of police complaints, fire and rescue and school reform, it is evident that the government must urgently reassess the PCC model. The quality of police and crime plans and the associated reports, suggests that, other than promoting an 'image' of effectiveness and proving the ability to cut financial costs, they have served largely to obscure the quality of police accountability in England and Wales. The presentation of an image of community engagement but without the substance appears to be by design. To suggest that PCCs have the spare capacity to effectively deliver an even broader mandate must surely be premised on the assumption that PCCs are effectively fulfilling their policing remit, which they are not. Viewing their performance through the prism of police and crime plans, PCCs have not displayed a clear ability to engage in comprehensive grass-roots consultation or effective police governance in practice. Their means, methods, actions and outcomes are considerably opaque, uncommunicated and ineffective.

To continue to build upon this foundation is likely to cause members of the public to become even more disillusioned with, rather than more confident in, police governance and the wider criminal justice apparatus. In the absence of a convincing body of evidence or 'any compelling reasons' to suggest that these initiatives will work (Stevens Commission 2013, p.80-84), the continued promotion of the 'orthodoxy' of PCCs appears to be emotional rather than rational. In the absence of clear information and convincing evidence within the police and crime plans and the associated reports, it is reckless for police forces and the government to simply assume there is a degree of civic participation taking place. As Kleinig (1996) has observed, police accountability is not only a normative demand that can be made but should be thought of structurally as a condition that exists. In the absence of clear community inputs and outputs, the present condition of police accountability in England and Wales appears to be in a remarkably poor state. It is clear that there needs to be a rethink of the constituent ingredients of the PCC model, particularly the role of the police and crime plan. This attempt to blend law, politics and precedent in an effort to realise local democratic accountability has arguably rendered the state of police accountability more illusory than ever before. 


\section{$\underline{\text { References }}$}

Adlam R., and Villiers, P. eds. (2003), Police Leadership in the Twenty-first Century. Waterside Press.

Adlam, R. (2003) 'Nice people, big questions, heritage concepts' in R. Adlam and P. Villiers, P. eds. Police Leadership in the Twenty-first Century. Waterside Press, 34-55

Banton, M. (1973), Police - Community Relations. Willan Publishing.

Bayley, D., and Shearing, C. (1996), 'The Future of Policing', Law \& Society Review, 30(3), 585-606.

Bittner, E. (1970), The Functions of the Police in Modern Society. Centre for Studies of Crime and Delinquency, National Institute of Mental Health, Maryland.

Brogden, M., and Nijar P. (2005), Community Policing: National and International models and approaches. Willan.

Caless, B. (2011), Policing at the Top: the roles, values and attitudes of chief police officers. Policy Press.

Caless B., and Owens, J. (2016), Police and Crime Commissioners: The transformation of police accountability. Policy Press.

Casciani, D. (2016), 'Police and Crime Commissioners: Unloved but Re-Elected', BBC News, 9 May 2016, accessed at http://www.bbc.co.uk/news/uk-politics-36248972

Fielding, N., and Innes, M. (2006), 'Reassurance Policing, Community Policing and Measuring Police Performance', Policing and Society, 16 (2), 127 - 145

GMPCC (2013a), Report on the Police and Crime Plan. Office of the Police and Crime Commissioner for Greater Manchester.

GMPCC (2013b), Report on the Police and Crime Plan for Salford. Office of the Police and Crime Commissioner for Greater Manchester.

GMPCC (2016a), Police and Crime Plan 2016 - 2017. Office of the Police and Crime Commissioner for Greater Manchester.

GMPCC (2016b), Annual Report 2015 - 2016. Office of the Police and Crime Commissioner for Greater Manchester.

Goldstein, H. (1990), Problem-Oriented Policing. McGraw Hill.

Gove, M. (2005), 'If crimes on the up, your Chief Constable must explain why or be sacked', The Times 15 March.

Greater Manchester Police (2013), Report to the Police and Crime Commissioner on the Force Delivery Plan. November 2013.

HASC (2010), Policing: Police and Crime Commissioners, House of Commons Home Affairs Committee Second Report of Session 2010-11, HC511.

HASC (2014), Police and Crime Commissioners: Progress to date, House of Commons Home Affairs Committee Sixteenth Report of the Session 2013-14, HC757.

HASC (2016), Police and Crime Commissioners: Here to Stay. House of Commons Home Affairs Committee Seventh Report of Session 2015-16, HC844.

HMIC (2005), Closing the Gap: A Review of the Fitness for Purpose of the Current Structure of Policing in England and Wales. London: Her Majesty's Inspectorate of Constabulary.

IPCC (2014), Police Handling of Allegations of Discrimination. Independent Police Complaints Commission.

Jackson J. et al (2012), 'Why do people comply with the law', British Journal of Criminology, 52, 1051-1071

Kelling, GL., and Wilson, JQ. (1982), 'Broken Windows: The Police and Neighbourhood Safety’, Atlantic Monthly, 249(3): 29-38.

Kleinig, J. (1996), The Ethics of Policing. Cambridge University Press. 
Klockars, C. (1985), The Idea of Police. Sage Publications

Lister, S., and Rowe, M. (2015), 'Electing police and crime commissioners in England and Wales: prospecting for the democratisation of policing', Policing and Society, 25:4

Loader, I. (2013), 'Why do the police matter? Beyond the myth of crime-fighting' in J. Brown, ed., The Future of Policing. London: Routledge, 40-51

Loader, I., and Mulcahy, A. (2003), Policing and the Condition of England: Memory, Politics and Culture. Oxford: Oxford University Press

Loader, I., and Sparks, R. (2002), 'Contemporary landscapes of crime, order and control: Governance, risk and globalization’ in M. Maguire, R. Morgan and R. Reiner, eds, The Oxford Handbook of Criminology, 83 - 106. Oxford University Press

Manning, PK. (1978), 'The Police Mandate: Strategies and Appearances' in Manning, PK., and Van Maanen, J., Policing: A View from the Streets. New York Random House.

Mawby, R. (2002), Policing Images: Policing, Communication and Legitimacy. Willan Publishing.

MOPAC (2013), Police and Crime Plan 2013 - 2016. The Mayor's Office for Policing and Crime. London.

MOPAC (2015), Annual Report 2014/15. The Mayor’s Office for Policing and Crime. London.

Newburn, T. (2012), 'Police and Crime Commissioners: The Americanization of Policing or a very British reform?’ International Journal of Law, Crime and Justice, 40 (1), 3146.

Neyroud, P., and Beckley A. (2001), Policing Ethics and Human Rights. Willan Publishing.

Perraudin, F. (2016), 'Nine in 10 say they cannot name local Police and Crime Commissioner', The Guardian, Saturday 30 April 2016.

Punch, M. (2009), Police Corruption: Deviance, Accountability and Reform in Policing. Routledge.

Raine, JW. (2016), 'Electocracy with Accountabilities? The Novel Governance Model of Police and Crime Commissioners' in S. Lister and M. Rowe, eds., Accountability of Policing, 114. Routledge.

Scarman, L (1981), The Scarman Report: The Brixton Disorders. London: HMSO.

Stevens Commission (2013), Policing for a Better Britain. Report of the Independent Police Commission. The Lord Stevens of Kirkwhelpington QPM.

West Midlands Strategic Policing and Crime Board (2016), Notes of meeting held on Tuesday, 7 June 2016. Birmingham City Council House, Birmingham.

West Midlands Strategic Policing and Crime Board (2016b), Performance against the 2015 16 milestones and deliverables in the Police and Crime Plan. Birmingham City Council House, Birmingham. 7 June 2016.

WMPCC (2013), Local Policing Plan Birmingham. Office of the Police and Crime Commissioner for the West Midlands Police.

WMPCC (2015a), The West Midlands Police and Crime Plan: Pride in Our Police 2015/16. Office of the Police and Crime Commissioner for the West Midlands Police.

WMPCC (2015b), Annual Report 2014-15. Office of the Police and Crime Commissioner for the West Midlands Police. 